www.nature.com $/ \mathrm{hr}$

\title{
REVIEW
}

\section{Increased arterial stiffness in obstructive sleep apnea: a systematic review}

\author{
Robert J Doonan ${ }^{1}$, Patrick Scheffler ${ }^{1}$, Marek Lalli ${ }^{1}$, R John Kimoff ${ }^{2}$, Eleni Th Petridou ${ }^{3}$, \\ Marios E Daskalopoulos ${ }^{4}$ and Stella S Daskalopoulou ${ }^{1}$
}

Obstructive sleep apnea is a prevalent disease that is associated with significant morbidity and mortality, particularly due to cardiovascular disease. An emerging cardiovascular risk factor, arterial stiffness, may also be involved in the cardiovascular complications of obstructive sleep apnea. The purpose of this review was to summarize the current literature regarding the effect of obstructive sleep apnea on arterial stiffness. We conducted a systematic literature review using PubMed, Embase and the Cochrane Library. We identified 24 studies that met search criteria investigating the effect of obstructive sleep apnea on arterial stiffness. Arterial stiffness was found to be increased in obstructive sleep apnea patients compared with controls or increased in severe compared with mild sleep apnea. In some studies, a positive correlation was identified between the degree of arterial stiffness and sleep apnea severity. In the two randomized, controlled trials and the two nonrandomized trials identified, treatment of obstructive sleep apnea with continuous positive airway pressure led to significant decreases in arterial stiffness. Obstructive sleep apnea appears to have an independent effect on arterial stiffness, which may be one of the mechanisms accounting for sleep apnea-associated cardiovascular risk. Hypertension Research (2011) 34, 23-32; doi:10.1038/hr.2010.200; published online 21 October 2010

Keywords: arterial stiffness; obstructive sleep apnea; pulse wave velocity; sleep disordered breathing

\section{BACKGROUND}

Obstructive sleep apnea (OSA) is a prevalent disease with roughly 1 of every 5 adults having at least mild OSA (defined by apnea-hypopnea index $(\mathrm{AHI}) \geqslant 5)$ and 1 of every 15 having at least moderate OSA $(\mathrm{AHI} \geqslant 15) .{ }^{1}$ The high prevalence rates are disturbing considering that OSA patients have an increased risk of morbidity and mortality, particularly due to cardiovascular disease..$^{2-7}$ OSA patients are often excessively sleepy during the daytime causing traffic crashes and work injuries, and they commonly have an increased number and severity of cardiovascular risk factors, such as hypertension, obesity, atherosclerosis, insulin resistance, the presence of increased inflammatory markers and endothelial dysfunction. ${ }^{8}$ Although OSA patients commonly demonstrate one or more established cardiovascular risk factors, there is now a considerable body of evidence indicating that OSA itself is an independent cardiovascular risk factor. ${ }^{3,9-16}$

Arterial stiffness determines how quickly the pulse wave generated by the contracting heart travels to the periphery and is reflected back. The larger arteries of the cardiovascular system are critical in the conduction of blood flow to the periphery. The elastic properties of these vessels, which are dependent on the stiffness of the arterial walls, allow for the smoothing of oscillations in blood pressure, reduction of the pulse pressure and perfusion of the myocardium. ${ }^{17,18}$ Central pressure and arterial stiffness offer an accurate estimation of the load imposed on the coronary arteries, cerebral arteries and aorta, and, in turn, of overall vascular damage and prognosis. ${ }^{19-24}$

Arterial stiffness can be measured noninvasively by applanation tonometry, echotracking and Doppler ultrasound. These techniques have very good reproducibility and have been widely applied. ${ }^{25}$ The most simple and reproducible noninvasive technique to date is the measurement of arterial waveforms (obtained by applanation tonometry), and more specifically pulse wave velocity (PWV), as recommended by the European Network for Non-invasive Investigation of Large Arteries ${ }^{25}$ and the European Society of Hypertension European Society of Cardiology Guidelines for the Management of Arterial Hypertension. ${ }^{26} \mathrm{PWV}$ is inversely related to arterial distensibility ${ }^{27}$ and expresses the speed of the pressure wave traveling through the arteries. The pulse travels at a higher velocity in a stiff artery, and vice versa. Carotid-femoral PWV (cfPWV) is considered the 'gold-standard' measurement of the stiffness of the aorta. ${ }^{25,26}$ It has been used extensively and has the largest amount of epidemiological evidence to support its predictive value for cardiovascular events in the general and diseased populations..$^{25,28-32}$

Measurements of arterial stiffness are believed to reflect global arterial endothelial function. ${ }^{33}$ A strong correlation between arterial stiffness and the development of atherosclerosis at various sites in the arterial tree has been noted. ${ }^{34-36}$ In fact, a recent study showed that

${ }^{1}$ Department of Medicine, Faculty of Medicine, McGill University, Montreal, Quebec, Canada; ${ }^{2}$ Sleep Laboratory, Respiratory Division, Department of Medicine, Faculty of Medicine, McGill University, Montreal, Quebec, Canada; ${ }^{3}$ Department of Hygiene, Epidemiology and Medical Statistics, Medical School, National and Kapodistrian University of Athens, Athens, Greece and ${ }^{4}$ Department of Vascular Surgery, Medical School, National and Kapodistrian University of Athens, Athens, Greece

Correspondence: Dr SS Daskalopoulou, FRSQ Chercheur-Boursier Clinicien, Division of Internal Medicine, Department of Medicine, McGill University Health Centre, Montreal General Hospital, McGill University, 1650 Cedar Avenue, B2.236, Montreal, Quebec, Canada H3G 1A4.

E-mail: stella.daskalopoulou@mcgill.ca

Received 25 April 2010; revised 30 July 2010; accepted 8 August 2010; published online 21 October 2010 
arterial stiffness is an early marker of atherosclerosis, as it is affected to a greater extent when compared with intima-media thickness in patients with vascular disease. ${ }^{37}$ This result is in line with another study, which showed that arterial stiffness is an independent predictor of vascular health and coronary artery disease above and beyond intima-media thickness. ${ }^{38}$ Arterial stiffness increases chronically with age, with the development of chronic conditions (for example, hypertension), and with the presence of vascular risk factors (for example, smoking). ${ }^{39-41}$

These observations have prompted researchers investigating OSAcardiovascular interactions to study the role of OSA in increasing arterial stiffness. The purpose of this systematic review was to collect evidence from the available literature regarding the effect of OSA on arterial stiffness to determine if arterial stiffness is increased in OSA patients.

\section{METHODS}

\section{Data sources and study selection}

Studies were identified through PubMed, Embase and the Cochrane Library using the keywords shown in Figure 1. Relevant articles were extracted using the search terms, reference lists and the 'related articles' links of articles selected for review. Included studies satisfied the following criteria: (1) controlled clinical observational studies and/or randomized controlled trials, and (2) the participants were OSA patients in which arterial stiffness was measured using a validated technique.

The search for articles was limited to those published between 1985 and November 2009, and written in English without any other limitations. Three independent researchers (RJD, PS and ML) conducted the search. All the authors participated in the final selection of the included studies.

\section{RESULTS}

Arterial stiffness in OSA vs. control groups: observational studies and baseline measurements from interventional studies

A total of 24 relevant studies were identified, confirmed by all authors and included in this review. Figure 1 illustrates the search and study selection procedure. Tables $1-3$ summarize the basic study and patient characteristics and the main findings of the included studies.

Several studies evaluated central arterial stiffness by measuring cfPWV. Tsioufis et al. ${ }^{42}$ found a higher cfPWV in OSA patients compared with controls. Drager et al. ${ }^{43}$ noted that although cfPWV was higher in OSA patients than in controls, it was even higher in OSA patients with hypertension. Another study by the same group compared the cfPWV of non-OSA controls with a mild to moderate OSA group, and a severe OSA group. Although they did not find the mild to moderate group to significantly differ from either the controls or the severe OSA group, they did note a significant difference between severe and non-OSA participants. A further study by Drager et al. ${ }^{44}$ examined the effect of the presence of OSA in patients with metabolic syndrome on arterial stiffness. They found cfPWV to be significantly higher in the presence as compared to the absence of OSA in these patients. Moreover, there was a significant positive correlation between cfPWV and AHI. ${ }^{45}$ A subsequent study by the same group examined arterial stiffness in OSA patients with and without masked hypertension. ${ }^{46}$ It was found that, whereas both types of OSA patients showed significantly higher arterial stiffness as compared to healthy controls, OSA patients with masked hypertension had the highest arterial stiffness. Chung et al. ${ }^{47}$ compared cfPWV in patients with mild to moderate OSA, severe OSA and control subjects. They found cfPWV to be significantly higher in patients with severe OSA as compared to both mild to moderate OSA and normal controls. Protogerou et al. ${ }^{48}$ determined $\mathrm{cfPWV}$, augmentation index (AIx) and central blood pressure in mild, moderate and severe OSA patients. They found that these arterial stiffness parameters did not increase with the severity of OSA after adjustment for age, gender, body mass index, heart rate, mean blood pressure, smoking and diabetes mellitus. However, respiratory disturbance index (RDI) was found to be an independent predictor of cfPWV.

Shiina et al. ${ }^{49}$ measured brachial-ankle PWV (baPWV) in OSA patients and found that they had a higher baPWV compared with

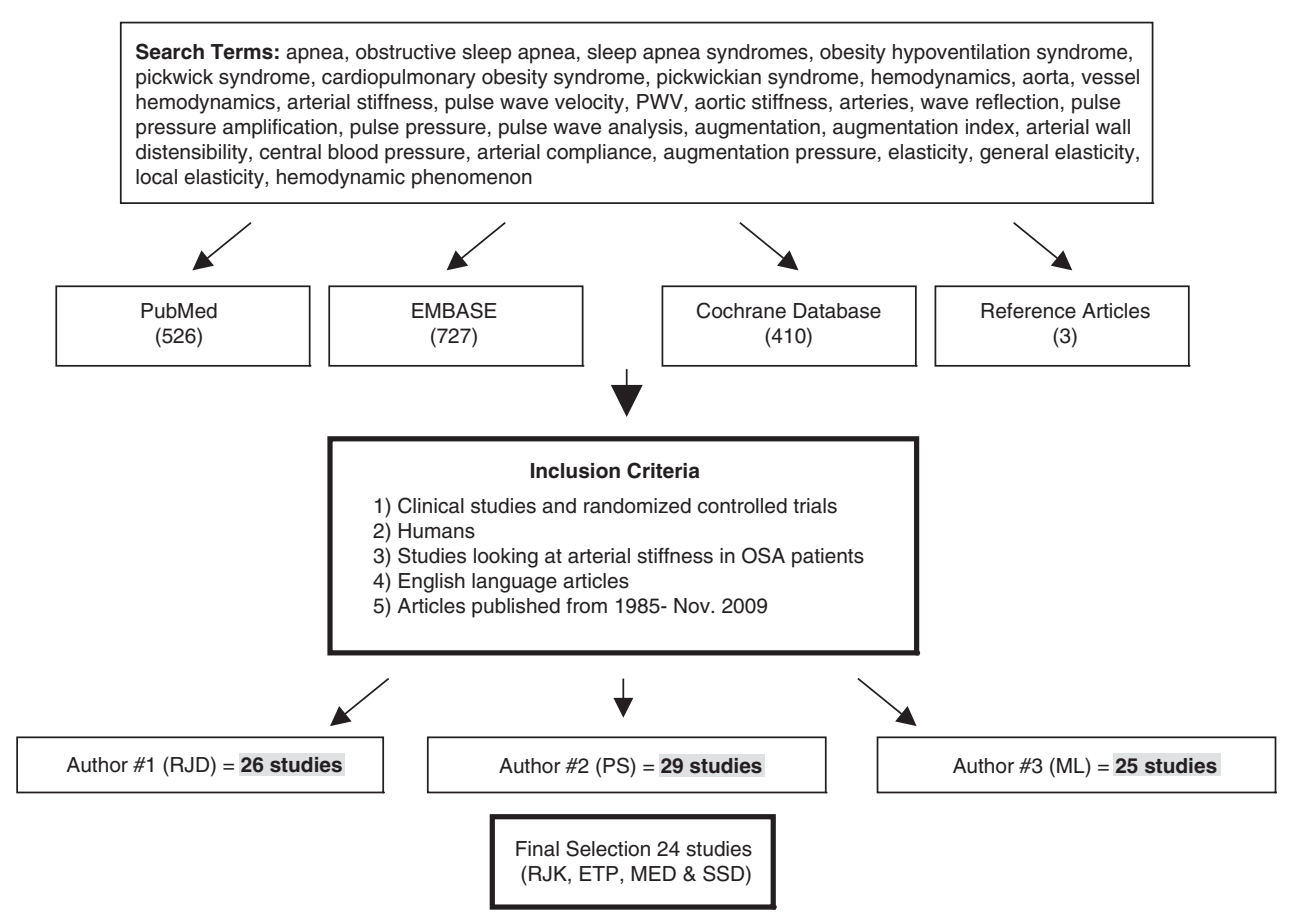

Figure 1 Search procedure. 
Table 1 Subject characteristics of included studies

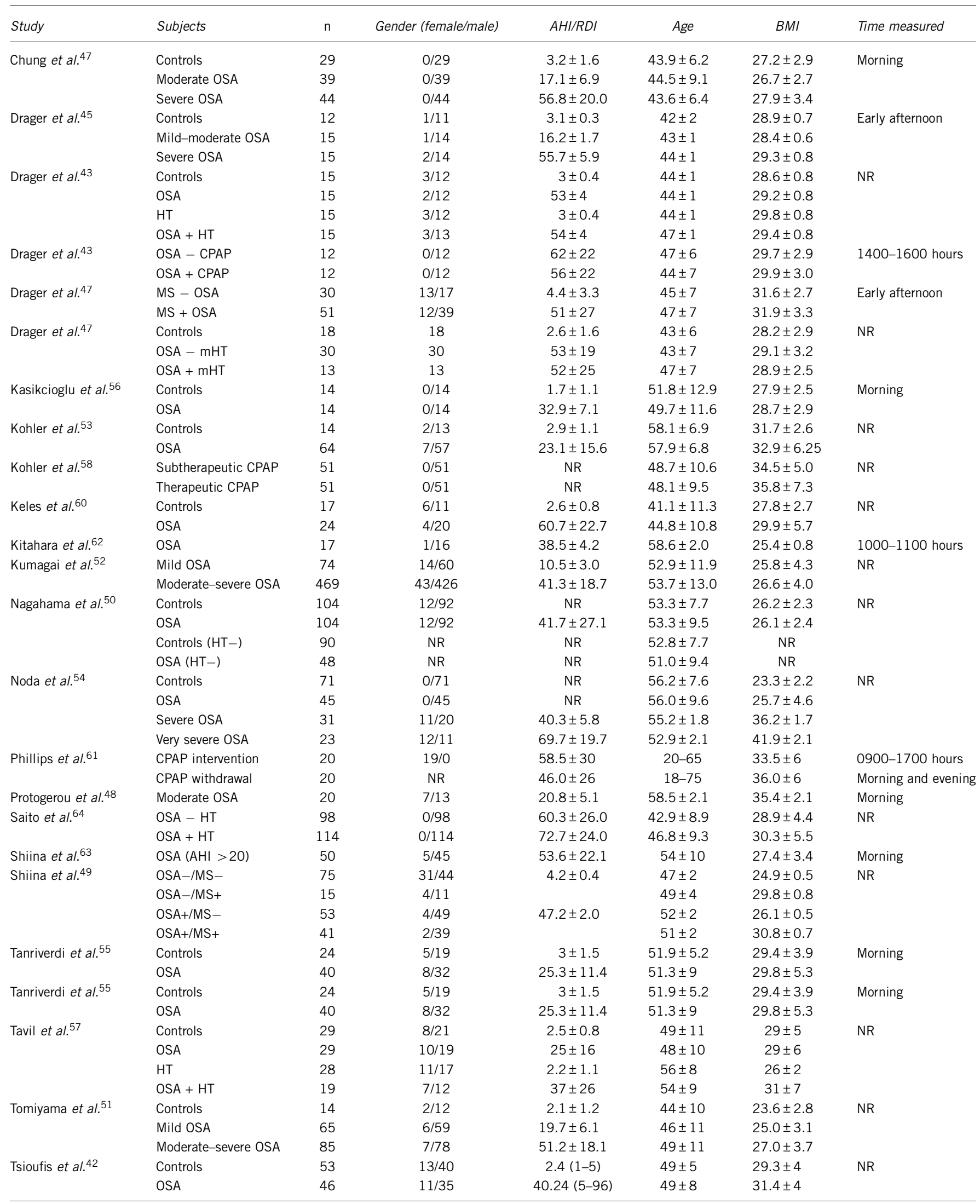

Abbreviations: AHI, apnea-hypopnea index; BMI, body mass index; CPAP, continuous positive airway pressure treatment; $\mathrm{HT}$, hypertension; mHT, masked hypertension; MS, metabolic syndrome; $\mathrm{NR}$, not reported; OSA, obstructive sleep apnea; RDI, respiratory disturbance index. 
Table 2 Arterial stiffness in OSA compared with control groups (cross-sectional studies)

\begin{tabular}{|c|c|c|c|c|}
\hline Study & Inclusion criteria & Comparison & Outcome & $\mathrm{P}$-value \\
\hline Chung et al. ${ }^{47}$ & $\begin{array}{l}\text { Male patients with untreated, } \\
\text { newly diagnosed OSA, free from } \\
\text { medication and inflammatory, } \\
\text { pulmonary and CVD }\end{array}$ & $\begin{array}{l}\text { Mild-moderate OSA } \\
(\mathrm{AHI}>5, \mathrm{AHI}<30) \\
\text { severe OSA }(\mathrm{AHI}>30) \text {, and } \\
\text { normal controls }\end{array}$ & $\begin{array}{l}\operatorname{cfPWV}(\mathrm{m} / \mathrm{s}) \\
\text { Controls: } 8.8 \pm 1.2 \\
\text { Moderate: } 9.0 \pm 1.4 \\
\text { Severe OSA: } 9.8 \pm 1.6\end{array}$ & $<0.01$ \\
\hline Drager et al. ${ }^{45}$ & $\begin{array}{l}\text { Patients with mild-moderate OSA } \\
\text { and severe OSA, with no history of } \\
\text { diabetes or HT }\end{array}$ & $\begin{array}{l}\text { Mild-moderate OSA, severe OSA } \\
\text { and matched controls with no OSA }\end{array}$ & $\begin{array}{l}\operatorname{cfPWV}(\mathrm{m} / \mathrm{s}) \\
\text { Controls: } 8.7 \pm 0.2 \\
\text { Mild-moderate OSA: } 9.2 \pm 0.2 \\
\text { Severe OSA: } 10.3 \pm 0.2 \\
\text { cfPWV significantly associated } \\
\text { with AHI: } r=0.61\end{array}$ & $\begin{array}{l}\text { Severe vs. mild-moderate }<0.01 \\
\text { Severe vs. controls }<0.001\end{array}$ \\
\hline Drager et al. ${ }^{43}$ & $\begin{array}{l}\text { Patients with severe OSA } \\
(\mathrm{AHI}>30 \text { events/h), no other } \\
\text { medical conditions except HT }\end{array}$ & $\begin{array}{l}\text { Comparison of controls with no } \\
\text { OSA, HT and OSA + HT }\end{array}$ & $\begin{array}{l}\text { cfPWV }(\mathrm{m} / \mathrm{s}) \text { Controls: } 8.7 \pm 0.3 \\
\text { OSA: } 10.2 \pm 0.2 \\
\text { HT: } 10.7 \pm 0.3 \\
\text { OSA + HT: } 12.1 \pm 0.4 \\
\text { cfPWV was independently associated } \\
\text { with AHI: } r=0.40\end{array}$ & $\begin{array}{l}\text { OSA and HT groups vs. } \\
\text { controls }<0.05 \\
\text { OSA + HT vs. controls }<0.01 \\
0.002\end{array}$ \\
\hline Drager et al. ${ }^{44}$ & $\begin{array}{l}\text { Patients recently diagnosed with } \\
\text { metabolic syndrome }\end{array}$ & $\begin{array}{l}\text { Metabolic syndrome patients with } \\
\text { and without OSA }\end{array}$ & $\begin{array}{l}\operatorname{cfPWV}(\mathrm{m} / \mathrm{s}) \\
\mathrm{MS}-\text { OSA: } 9.6 \pm 1.0 \\
\mathrm{MS}+\text { OSA: } 10.6 \pm 1.6\end{array}$ & $<0.001$ \\
\hline Drager et al. ${ }^{44}$ & $\begin{array}{l}\text { Male normotensive patients with or } \\
\text { without masked hypertension and } \\
\text { with moderate-severe OSA }\end{array}$ & $\begin{array}{l}\text { Age- and BMI-matched healthy } \\
\text { controls }\end{array}$ & $\begin{array}{l}\operatorname{cfPWV}(\mathrm{m} / \mathrm{s}) \\
\text { Controls: } 8.7 \pm 0.7 \\
\text { OSA }-\mathrm{mHT}: 9.4 \pm 1.0 \\
\text { OSA + mHT: } 10.6 \pm 1.1\end{array}$ & $\begin{array}{l}\text { Controls vs. OSA-mHT: } 0.004 \\
\text { Controls vs. OSA+mHT: } 0.002 \\
\text { OSA-mHT vs. OSA+mHT: }<0.001\end{array}$ \\
\hline \multirow[t]{3}{*}{$\begin{array}{l}\text { Kasikcioglu } \\
\text { et al. }{ }^{56}\end{array}$} & $\begin{array}{l}\text { Patients with newly diagnosed } \\
\text { moderate-severe OSA, normotensive, } \\
\text { no medications }\end{array}$ & $\begin{array}{l}\text { OSA patients, matched controls } \\
\text { with no OSA }\end{array}$ & $\begin{array}{l}\text { Stiffness index (\%) } \\
\text { Controls: } 2.1 \pm 0.1 \\
\text { OSA: } 4.5 \pm 0.3\end{array}$ & 0.001 \\
\hline & & & $\begin{array}{l}\text { Correlation between aortic stiffness } \\
\text { and } \mathrm{AHI} \text { : coefficient }=0.49\end{array}$ & 0.002 \\
\hline & & & $\begin{array}{l}\text { Aortic distensibility }\left(10^{-6} \mathrm{~cm}^{2} / \text { dyn }\right) \\
\text { Controls: } 3.9 \pm 1.5 \\
\text { OSA: } 2.4 \pm 1.2\end{array}$ & 0.009 \\
\hline Kohler et al. ${ }^{53}$ & $\begin{array}{l}\text { Patients with OSA, no history of } \\
\text { excessive daytime sleepiness that } \\
\text { would justify CPAP therapy }\end{array}$ & Patients with and without OSA & $\begin{array}{l}\text { Alx }(\%) \\
\text { Controls: } 21.0(8.0-27.0) \\
\text { OSA: } 26.0(19.0-29.5)\end{array}$ & 0.04 \\
\hline Kumagai et al. ${ }^{52}$ & $\begin{array}{l}\text { Patients with OSA, without CVD, } \\
\text { cerebrovascular or renal disease }\end{array}$ & $\begin{array}{l}\text { Mild OSA }(\mathrm{AHI}>5, \mathrm{AHI}<15) \\
\text { moderate-severe OSA }(\mathrm{AHI}>15)\end{array}$ & $\begin{array}{l}\text { Cardio-ankle vascular index }(\mathrm{m} / \mathrm{s}) \\
\text { Mild OSA: } 7.3 \pm 1.2 \\
\text { Moderate-severe OSA: } 7.7 \pm 1.4\end{array}$ & 0.034 \\
\hline $\begin{array}{l}\text { Nagahama } \\
\text { et al. } 50\end{array}$ & OSA patients with or without HT & $\begin{array}{l}\text { OSA patients with and without } \mathrm{HT} \text {, } \\
\text { matched controls with no OSA } \\
\text { with and without HT }\end{array}$ & $\begin{array}{l}\text { baPWV ( } \mathrm{m} / \mathrm{s} \text { ) } \\
\text { Controls (with and without HT): } \\
14.36 \pm 2.78 \\
\text { OSA (with and without HT): } \\
16.45 \pm 3.49 \\
\text { Controls (no HT): } 13.74 \pm 2.13 \\
\text { OSA (no HT): } 14.53 \pm 2.16 \\
\text { Controls (no risk factors): } 11.98 \pm 0.79 \\
\text { OSA (no risk factors): } 14.00 \pm 2.00\end{array}$ & $\begin{array}{l}<0.05 \\
<0.05\end{array}$ \\
\hline Noda et al. ${ }^{54}$ & $\begin{array}{l}\text { Male OSA patients referred to sleep } \\
\text { clinic for screening and treatment, } \\
\text { free from medication, no history } \\
\text { of CVD }\end{array}$ & $\begin{array}{l}\text { OSA patients and matched controls } \\
\text { with no OSA }\end{array}$ & $\begin{array}{l}\text { Alx (\%) } \\
\text { Controls: } 18.6 \pm 9.0 \\
\text { OSA: } 23.5 \pm 8.7 \\
\text { Aortic augmentation pressure }(\mathrm{mm} \mathrm{Hg}) \\
\text { Controls: } 6.4 \pm 3.4 \\
\text { OSA: } 9.0 \pm 4.1\end{array}$ & $<0.001$ \\
\hline $\begin{array}{l}\text { Protogerou } \\
\text { et al. }{ }^{48}\end{array}$ & Patients with OSA with RDI $\geqslant 10$ & $\begin{array}{l}\text { Moderate OSA (RDI = 10-30), } \\
\text { severe OSA (RDI = 31-50) } \\
\text { and very severe OSA (RDI > 50) }\end{array}$ & $\begin{array}{l}\text { Alx }(\%) \\
\text { Moderate OSA: } 102.1 \pm 5.9 \\
\text { Severe OSA: } 110.0 \pm 4.6 \\
\text { Very severe OSA: } 109.4 \pm 6.8 \\
\text { cfPWV (m/s) } \\
\text { Moderate OSA: } 8.5 \pm 0.6\end{array}$ & 0.227 (NS) \\
\hline
\end{tabular}


Table 2 Continued

\begin{tabular}{|c|c|c|c|c|}
\hline & & & $\begin{array}{l}\text { Severe OSA: } 8.7 \pm 0.4 \\
\text { Very Severe OSA: } 10.2 \pm 0.7 \\
\text { RDI was an independent } \\
\text { predictor of cfPWV: } \\
\beta=0.359, r^{2}=12 \%\end{array}$ & 0.016 \\
\hline \multirow[t]{2}{*}{ Shiina et al. ${ }^{49}$} & \multirow[t]{2}{*}{$\begin{array}{l}\text { Patients referred for treatment of } \\
\text { OSA, no medical history of heart } \\
\text { disease or stroke }\end{array}$} & \multirow[t]{2}{*}{$\begin{array}{l}\text { OSA patients, matched controls } \\
\text { with no OSA }\end{array}$} & $\begin{array}{l}\text { baPWV }(\mathrm{m} / \mathrm{s}) \\
\text { baPWV was higher in patients with OSA } \\
\text { than without OSA }\end{array}$ & $<0.05$ \\
\hline & & & $\begin{array}{l}\text { Significant correlation between } \\
\text { OSA and baPWV: } r^{2}=0.41\end{array}$ & $<0.01$ \\
\hline $\begin{array}{l}\text { Tanriverdi } \\
\text { et al. }{ }^{55}\end{array}$ & $\begin{array}{l}\text { Patients with no cardiovascular } \\
\text { conditions referred for evaluation of } \\
\text { snoring and possible sleep apnea }\end{array}$ & $\begin{array}{l}\text { OSA patients, matched controls } \\
\text { with no OSA }\end{array}$ & $\begin{array}{l}\text { Stiffness index (\%) } \\
\text { Controls: } 6.42 \pm 1.56 \\
\text { OSA: } 7.1 \pm 1.88 \\
\text { Distensibility }\left(10^{-6} \mathrm{~cm}^{2} / \text { dyn }\right) \\
\text { Controls: } 11.8 \pm 3.36 \\
\text { OSA: } 9.47 \pm 1.33\end{array}$ & 0.0001 \\
\hline Tavil et al. ${ }^{57}$ & $\begin{array}{l}\text { Patients with } \mathrm{HT} \text {, OSA or OSA } \\
\text { and } \mathrm{HT}\end{array}$ & $\mathrm{OSA}, \mathrm{HT}$ and $\mathrm{OSA}+\mathrm{HT}$ & $\begin{array}{l}\text { Aortic strain (\%) } \\
\text { Controls: } 13.7 \pm 4.5 \\
\text { OSA: } 6.1 \pm 2.7 \\
\text { HT: } 6.4 \pm 2.4 \\
\text { OSA + HT: } 4.7 \pm 1.8 \\
\text { Distensibility }\left(10^{-6} \mathrm{~cm}^{2} / \text { dyn) }\right. \\
\text { Controls: } 6.2 \pm 3.2 \\
\text { OSA: } 2.8 \pm 1.6 \\
\text { HT: } 2.5 \pm 0.9 \\
\text { OSA + HT: } 1.7 \pm 0.7\end{array}$ & $\begin{array}{l}\text { Controls vs. all groups } 0.001 \\
\text { OSA + HT vs. all groups } 0.001\end{array}$ \\
\hline
\end{tabular}

Abbreviations: AHI, apnea-hypopnea index; Alx, augmentation index; Alx(75), augmentation index corrected to a heart rate of 75 b.p.m.; baPWV, brachial-ankle pulse wave velocity; BP, blood pressure; cfPWV, carotid-femoral pulse wave velocity; CVD, cardiovascular disease; $\mathrm{HT}$, hypertension; $\mathrm{mHT}$, masked hypertension; OSA, obstructive sleep apnea; RDI, respiratory disturbance index.

those without OSA. In addition, a significant independent correlation between OSA and baPWV was noted. Similarly, another study observed that baPWV was higher in OSA compared with OSA-free control patients. This trend was maintained even in individuals free of hypertension and cardiovascular risk factors, indicating that OSA itself may be involved in the causation of stiffening of the arteries. ${ }^{50}$ This conclusion is strengthened by the findings of Tomiyama et al., ${ }^{51}$ who found AHI to be an independent predictor of baPWV. Furthermore, Kumagai et al. ${ }^{52}$ compared patients with mild and moderate to severe OSA using the cardio-ankle vascular index. They found cardio-ankle vascular index to be lower in patients with mild OSA as compared to patients with moderate to severe OSA.

Kohler et al. ${ }^{53}$ evaluated the stiffness of the arteries in minimally symptomatic OSA patients using AIx. They found increased AIx in OSA patients compared with controls. Likewise, Noda et al. ${ }^{54}$ noted an increased AIx in OSA patients compared with non-OSA controls.
Several studies used ultrasonographic methods to evaluate arterial stiffness in OSA patients. Tanriverdi et al. ${ }^{55}$ found that the stiffness index of OSA patients was higher as compared to control patients, and that aortic distensibility was lower than in control patients. They also noted a correlation between aortic stiffness and RDI as well as a negative correlation between RDI and distensibility $(r=-0.41$, $P=0.001)$. Kasikcioglu et al. ${ }^{56}$ found decreased aortic distensibility and increased stiffness index in OSA patients compared with controls. These findings were furthered by another study that found decreased distensibility in OSA patients compared with controls and a further decrease in OSA hypertensive patients. ${ }^{57}$

\section{Effects of continuous positive airway pressure treatment on arterial} stiffness

Kohler et al. ${ }^{58}$ randomized 102 male OSA patients to 4 weeks of therapeutic or subtherapeutic effects of continuous positive airway 
Table 3 Continuous positive airway pressure treatment and arterial stiffness (randomized and nonrandomized studies)

\begin{tabular}{|c|c|c|c|c|}
\hline Study & Inclusion criteria & Comparison & Outcome & P-value \\
\hline \multirow[t]{3}{*}{ Drager et al. ${ }^{43}$} & \multirow[t]{3}{*}{$\begin{array}{l}\text { Nonsmoking patients with untreated, severe OSA } \\
\text { with no cardiovascular or renal conditions, } \\
\text { diabetes and not on medication }\end{array}$} & \multirow[t]{3}{*}{$\begin{array}{l}\text { CPAP or no CPAP; } \\
\text { Repeated measures after } 4 \text { months }\end{array}$} & $\begin{array}{l}\operatorname{cfPWV}(\mathrm{m} / \mathrm{s}) \\
\text { Controls baseline: } 10.1 \pm 1.3 \\
\text { Controls } 4 \text { months: } 10.3 \pm 1.3\end{array}$ & NS \\
\hline & & & $\begin{array}{l}\text { CPAP baseline: } 10.4 \pm 1.0 \\
\text { CPAP } 4 \text { Months: } 9.3 \pm 0.9\end{array}$ & $<0.001$ \\
\hline & & & Controls vs. CPAP 4 months & $<0.001$ \\
\hline \multirow[t]{21}{*}{ Keles et al. ${ }^{60}$} & \multirow[t]{21}{*}{$\begin{array}{l}\text { Patients referred for overnight } \\
\text { polysomnography to diagnose OSA } \\
\text { with no cardiovascular or } \\
\text { pulmonary conditions }\end{array}$} & \multirow[t]{21}{*}{$\begin{array}{l}\text { Healthy controls; } \\
\text { Repeated measures after } 6 \text { months } \\
\text { of CPAP treatment }\end{array}$} & $\begin{array}{l}\text { Aortic strain (\%) } \\
\text { Controls: } 12.4 \pm 3.1 \\
\text { OSA: } 6.7 \pm 2.1 \\
\text { After Treatment: } 7.3 \pm 1.7\end{array}$ & $\begin{array}{r}<0.001 \\
0.007\end{array}$ \\
\hline & & & Sig. correlation with $\mathrm{AHI}: r=-0.63$ & $<0.001$ \\
\hline & & & Aortic distensibility ( $\left.\mathrm{cm}^{2} / d y n\right)$ & $<0.001$ \\
\hline & & & Controls: $5.5 \pm 1.7 \times 10^{-6}$ & 0.01 \\
\hline & & & OSA: $2.8 \pm 0.9 \times 10^{-6}$ & $<0.001$ \\
\hline & & & After Treatment: $3.1 \pm 0.9 \times 10^{-6}$ & \\
\hline & & & Sig. correlation with $\mathrm{AHI}: r=-0.62$ & \\
\hline & & & Aortic systolic diameter (mm) & 0.48 \\
\hline & & & Controls: $32.1 \pm 2.2$ & NS \\
\hline & & & OSA: $32.6 \pm 2.0$ & \\
\hline & & & After treatment: $32.2 \pm 2.1$ & \\
\hline & & & Aortic diastolic diameter ( $\mathrm{mm}$ ) & 0.001 \\
\hline & & & Controls: $28.1 \pm 2.3$ & $<0.001$ \\
\hline & & & OSA: $30.3 \pm 1.7$ & 0.001 \\
\hline & & & After treatment: $29.8 \pm 1.8$ & \\
\hline & & & Sig. correlation with $\mathrm{AHI}: r=0.496$ & \\
\hline & & & Pulsatile diameter change ( $\mathrm{mm}$ ) & $<0.001$ \\
\hline & & & Controls: $4.0 \pm 1.0$ & 0.01 \\
\hline & & & OSA: $2.2 \pm 0.8$ & $<0.001$ \\
\hline & & & After treatment: $2.36 \pm 0.6$ & \\
\hline & & & Sig. correlation with $\mathrm{AHI}: r=-0.58$ & \\
\hline \multirow[t]{5}{*}{ Kitahara et al. ${ }^{62}$} & \multirow{5}{*}{$\begin{array}{l}\text { Patients with newly diagnosed } \\
\text { untreated OSA }\end{array}$} & \multirow{5}{*}{$\begin{array}{l}\text { Repeated measures after } 2 \text { and } \\
4 \text { months of CPAP treatment }\end{array}$} & $b a P W V(m / s)$ & 0.01 \\
\hline & & & Start: $15.6 \pm 0.6$ & 0.027 \\
\hline & & & 2 months: $15.0 \pm 0.5$ & \\
\hline & & & 4 months: $14.9 \pm 0.6$ & \\
\hline & & & $\begin{array}{l}\text { Correlation between baPWV and arousal } \\
\text { index: } r=0.596\end{array}$ & 0.012 \\
\hline \multirow[t]{6}{*}{ Kohler et al., 2008} & \multirow{6}{*}{$\begin{array}{l}\text { Patients referred for overnight } \\
\text { polysomnography to diagnose } \\
\text { OSA with ODI > } 10\end{array}$} & \multirow{6}{*}{$\begin{array}{l}\text { Subtherapeutic and therapeutic } \\
\text { CPAP after } 4 \text { months }\end{array}$} & $A / x(\%)$ & \\
\hline & & & Subtherapeutic baseline: $12.2 \pm 13.6$ & \\
\hline & & & Subtherapeutic 4 months: $14.2 \pm 14.9$ & \\
\hline & & & Therapeutic baseline: $14.5 \pm 11.3$ & \\
\hline & & & Therapeutic 4 months: $9.1 \pm 13.8$ & \\
\hline & & & $\begin{array}{l}\text { Therapeutic CPAP decreased Alx compared } \\
\text { with subtherapeutic CPAP }\end{array}$ & 0.001 \\
\hline \multirow[t]{16}{*}{ Phillips et al. ${ }^{61}$} & \multirow{9}{*}{$\begin{array}{l}\text { Intervention study: male, } \\
\text { 20-65-year-old, untreated } \\
\text { OSA patients with RDI > } 25\end{array}$} & \multirow{9}{*}{$\begin{array}{l}\text { None-repeated measures after } \\
2 \text { months of CPAP treatment }\end{array}$} & Peripheral systolic BP ( $\mathrm{mm} \mathrm{Hg})$ & 0.3 (NS) \\
\hline & & & Pre-intervention: $126.8 \pm 12$ & \\
\hline & & & Post-intervention: $123.8 \pm 13$ & \\
\hline & & & Central systolic BP ( $\mathrm{mm} \mathrm{Hg})$ & 0.043 \\
\hline & & & Pre-intervention: $115.1 \pm 12$ & \\
\hline & & & Post-intervention: $110.9 \pm 12$ & \\
\hline & & & Aix75 (\%) & 0.015 \\
\hline & & & Pre-intervention: $14.4 \pm 9.3$ & \\
\hline & & & Post-intervention: $11.9 \pm 8.6$ & \\
\hline & \multirow{7}{*}{$\begin{array}{l}\text { Withdrawal study: } 18 \text { - to } 75 \text {-year-old } \\
\text { patients, on CPAP for at least } 1 \text { year, with } \\
\text { RDI }>15 \text { events per hour at diagnosis } \\
\text { and } \mathrm{AHI}<10 \text { after CPAP treatment }\end{array}$} & \multirow{7}{*}{$\begin{array}{l}\text { None-repeated measures after } \\
7 \text { nights of CPAP withdrawal }\end{array}$} & Peripheral systolic BP $(\mathrm{mm} \mathrm{Hg})$ & NS \\
\hline & & & No significant change & \\
\hline & & & No exact values provided & \\
\hline & & & & \\
\hline & & & Alx75 (\%) & \\
\hline & & & No significant change & \\
\hline & & & No exact values provided & \\
\hline
\end{tabular}


Table 3 Continued

\begin{tabular}{|c|c|c|c|c|}
\hline Study & Inclusion criteria & Comparison & Outcome & $\mathrm{P}$-value \\
\hline Saito et al. ${ }^{64}$ & $\begin{array}{l}\text { Normotensive or hypertensive patients } \\
\text { with moderate-severe OSA who had been } \\
\text { on CPAP treatment for } 2 \text { years, and had hypertension }\end{array}$ & $\begin{array}{l}\text { Repeated measures after } 6,12 \text { and } \\
24 \text { months of CPAP treatment }\end{array}$ & $\begin{array}{l}\text { baPWV }(\mathrm{m} / \mathrm{s}) \\
\text { Baseline: } 14.6 \pm 2.1 \\
6 \text { months: } 14.1 \pm 2.1 \\
12 \text { months: } 14.3 \pm 2.2 \\
24 \text { months: } 14.5 \pm 2.3\end{array}$ & $\begin{array}{c}<0.001 \\
<0.05 \\
\text { NS }\end{array}$ \\
\hline Shiina et al. ${ }^{63}$ & $\begin{array}{l}\text { Patients referred for treatment of OSA, } \\
\text { no history of heart disease or diabetes }\end{array}$ & $\begin{array}{l}\text { Repeated measures after } 3 \text { months } \\
\text { of CPAP treatment }\end{array}$ & $\begin{array}{l}\text { baPWV }(\mathrm{m} / \mathrm{s}) \\
\text { Pre-intervention: } 15.4 \pm 0.3 \\
\text { Post-intervention: } 14.5 \pm 0.3\end{array}$ & 0.001 \\
\hline
\end{tabular}

Abbreviations: AHI, apnea-hypopnea index; Alx, augmentation index; AIx(75), augmentation index corrected to a heart rate of 75b.p.m.; baPWV, brachial-ankle pulse wave velocity; BP, blood pressure; cfPWV, carotid-femoral pulse wave velocity; CPAP, continuous positive airway pressure; CVD, cardiovascular disease; HT, hypertension; $\mathrm{mHT}$, masked hypertension; ODI, oxygen desaturation index; OSA, obstructive sleep apnea; RDI, respiratory disturbance index.

pressure (CPAP). They noted a decrease in AIx in the therapeutic group compared with a slight, nonsignificant increase in the subtherapeutic group. ${ }^{58}$ They also tested the sensitivity of the baroreflex at these time points, and found significant improvements following only therapeutic CPAP. The authors hypothesized that CPAP may improve arterial stiffness by acting upon baroreflex sensitivity. Drager et al. ${ }^{59}$ performed a similar study with 4 months of CPAP, examining cfPWV, which is the 'gold standard' for arterial stiffness measurements. The CPAP group had a decrease in cfPWV, C-reactive protein and catecholamines, whereas changes in the non-CPAP control group were not significant. ${ }^{59}$

Furthermore, we identified five nonrandomized clinical observational studies. Keles et al. ${ }^{60}$ measured aortic elastic parameters, aortic strain and aortic distensibility using echocardiography in 24 patients with newly diagnosed, previously untreated, moderate or severe OSA and 17 healthy controls. Following 6 months of CPAP treatment, measurements were repeated in the OSA group, and a significant improvement in aortic elastic parameters was found. Similarly, Phillips et al. ${ }^{61}$ found that 2 months of CPAP treatment significantly decreased AIx, but not peripheral blood pressure. In the same study, withdrawing CPAP for a week in patients who had undergone CPAP treatment for at least 1 year did not significantly affect AIx, but led to an increase in peripheral blood pressure in the morning as compared to the late evening. ${ }^{61}$ A study by Kitahara et al. ${ }^{62}$ found that 4 months of CPAP treatment significantly decreased baPWV. Furthermore, they found a significant correlation between the severity of sleep apnea, as measured by arousal index, and baPWV. Similarly, Shiina et al. ${ }^{63}$ found 3 months of CPAP to lead to a significant decrease in baPWV but not peripheral blood pressure. Saito et al., ${ }^{64}$ however, found 6 months of CPAP treatment to decrease both baPWV and peripheral blood pressure in both hypertensive and normotensive patients. Interestingly, following the significant decrease observed after the first 6 months of treatment, baPWV gradually increased in both groups over the following 18 months under study, whereas peripheral blood pressure did not.

\section{DISCUSSION}

This systematic review has presented data from 24 studies evaluating the effect of OSA on arterial stiffness. The results indicate that arterial stiffness is increased in OSA patients, and the majority of the studies point to an association between the severity of OSA and the magnitude of the effect on arterial stiffness. The consistency of the literature is of note. All studies presented in this review found an association of OSA and arterial stiffness. As to the association between the severity of OSA and arterial stiffness, the literature is somewhat less consistent.
Out of the seven studies investigating the association between severity of OSA and arterial stiffness, ${ }^{45,47,48,51,52,60,62}$ six provided full support for the association ${ }^{45,47,51,52,60,62}$ and one provided mixed results. ${ }^{48}$ More specifically, the study by Protogerou et al ${ }^{48}$ did not find a direct association between OSA severity categories (moderate, severe and very severe) and arterial stiffness. However, they did find RDI to predict cfPWV significantly, the gold standard of arterial stiffness measurements. This is in line with findings by Keles et al. ${ }^{60}$ who found a significant correlation between AHI and aortic elastic parameters. Clearly, more research is needed to further our understanding of this association.

The results presented in this review are in keeping with previous studies evaluating endothelial function of OSA patients using flowmediated dilation. Numerous studies noted that flow-mediated dilation, measured locally in the brachial artery, was decreased in OSA patients compared with non-OSA controls, ${ }^{2,53,65-67}$ indicating that endothelial dysfunction occurs in OSA. However, here we discuss the available literature that furthers our understanding of the effect of OSA on arterial function, showing that not only local, but also global arterial function is impaired in OSA.

One of the strongest lines of evidence supporting an independent effect of OSA on arterial stiffness is the finding of the two randomized, controlled studies performed to date, which found that CPAP treatment of OSA significantly improved arterial stiffness. ${ }^{58,59}$ Similar findings have also been reported from other studies evaluating OSA treatment effects on arterial stiffness which did not meet our inclusion criteria. ${ }^{68}$ Also of note, Phillips et al. ${ }^{61}$ found that 8 weeks of CPAP treatment lead to reductions in AIx and central systolic blood pressure without a concomitant decrease in peripheral blood pressure. Thus, although the numbers are relatively small in the randomized studies to date, and further larger studies are required with longer follow-up of both arterial stiffness and cardiovascular event outcomes, the current literature points to an independent association between OSA and arterial stiffness. However, as only two randomized trials have been performed to date, more randomized trials are needed to further explore this relationship.

Importantly, it should be noted that arterial stiffness was found to be elevated throughout the day, in the awake state. This implies a carryover effect of OSA on arterial stiffness. More specifically, arterial stiffness is not only elevated acutely at night, when the respiratory disturbance occurs, as shown by Jelic et al. ${ }^{69}$ but also during the awake state.

\section{Mechanisms}

A number of mechanisms could explain the role of OSA in increasing arterial stiffness. Inflammation, oxidative stress and sympathetic 
activity affect endothelial function and are all altered in OSA.9,10 Intermittent hypoxia is associated with increased production of reactive oxygen species, and therefore, increases oxidative stress. ${ }^{70,71}$ Prolonged oxidative stress disturbs cellular function, promotes endothelial dysfunction and increases inflammation, which can further increase the metabolic and cardiovascular complications of OSA such as atherosclerosis. ${ }^{70}$ Oxidative stress also reduces the activity of nitric oxide synthase and thus leads to decreased production of nitric oxide, increasing arterial stiffness. ${ }^{72}$ Various studies have also found that C-reactive protein, tumor necrosis factor- $\alpha$, interleukin-6 (IL-6), IL-8 and cell adhesion molecules such as intercellular adhesion molecule- 1 are increased in the circulation in OSA patients independent of obesity. ${ }^{10,15,73,74}$ Increased inflammation may have a role in the pathogenesis of OSA, increasing arterial stiffness and contributing to the early atherosclerosis found in OSA patients. ${ }^{3}$ Furthermore, it also appears that endothelial dysfunction in OSA is partially mediated through apoptotic dysregulation; circulating apoptotic endothelial cells were found to be associated with AHI $(r=0.56, P=0.004)$. This was partially reversed after 8 weeks of CPAP treatment. ${ }^{2}$

\section{Therapeutic and clinical implications}

It has been well established that OSA is an independent risk factor for hypertension, myocardial infarction and stroke. ${ }^{2-7}$ Arterial stiffness is independently associated with cardiovascular risk ${ }^{19-24,26,28-31,75-78}$ and may therefore provide a potential explanation for the increased risk of cardiovascular events in OSA patients. Furthermore, a strong correlation between arterial stiffness and the development of atherosclerosis at various sites in the arteries has been noted..$^{35,36}$ Therefore, measuring arterial stiffness can be an important clinical tool for the monitoring of disease progression and treatment efficacy, as recommended by the European Network for Non-invasive Investigation of Large Arteries ${ }^{25}$ and the 2007 European guidelines for the management of arterial hypertension. ${ }^{26}$ The use of arterial stiffness measurements may be particularly useful in assessing the endothelial damage induced by certain cardiovascular risk factors, such as OSA. However, not all parameters of arterial stiffness are equal; cfPWV is the best measure of arterial stiffness. It is considered the 'gold standard' for the assessment of aortic stiffness, ${ }^{25,26}$ and cfPWV and AIx have the greatest amount of evidence to support their predictive value for cardiovascular events in healthy and diseased populations. ${ }^{26,28-30,75,79,80}$ Therefore, other parameters of arterial stiffness, such as local distensibility or compliance, may not be as valuable to assess the vascular effects of OSA and are not as useful clinical parameters.

\section{Limitations}

This review has a number of limitations. First, the studies use slightly different protocols and methods; the time of day and the conditions under which the studies took place (for example, fasting) were not standardized between studies or not reported. Furthermore, the age groups of subjects, severity of OSA, body mass index, renal function, lipid profile, menopausal status, medication use, including statin use, were not uniform between studies or subject groups. Furthermore, studies were typically cross-sectional, with small sample sizes, and links to long-term outcomes (for example, cardiovascular events or progression of sleep apnea) have yet to be investigated. Moreover, studies examining the effect of CPAP on arterial stiffness have had short follow-ups, thereby not providing information about long-term outcomes.

These factors were also often not reported or corrected for; clearly, future studies should recruit more homogeneous populations. The methods of assessing arterial stiffness also differed between studies; however, it is encouraging that eight studies used cfPWV, AIx or both as parameters of arterial stiffness. ${ }^{42-45,47,48,53,54}$ Furthermore, limiting our search to English language publications may have led to an omission of potentially relevant studies. Owing to methodological constraints, a meta-analysis of studies aiming to also quantify the overall magnitude of the effect of OSA on arterial stiffness could not be conducted.

Many studies did not report the time of the day at which arterial stiffness measurements were performed. A study by Phillips et al. ${ }^{81}$ demonstrated circadian variation of arterial stiffness in OSA patients. More specifically, arterial stiffness was found to be higher in the morning as opposed to the evening. Although Phillips et al. did not recruit healthy controls to compare this effect in both healthy and OSA patients, other studies have shown this circadian effect also in healthy populations. ${ }^{82}$ Furthermore, a study in healthy individuals by Papaioannou et al. ${ }^{82}$ suggested that the aforementioned circadian effect is at least in part due to increased blood pressure in the morning. As to OSA patients, it may represent a carryover effect from increased stiffness as well as blood pressure observed during respiratory disturbances at night. ${ }^{69}$ Nevertheless, it should be noted that this effect still bears importance, as most cardiovascular events take place in the morning. ${ }^{83,84}$

\section{CONCLUSION}

To the best of our knowledge this is the first systematic review on the effect of OSA on arterial stiffness. We have reviewed results from 24 studies evaluating the effect of OSA on arterial stiffness. Arterial stiffness is increased in OSA patients compared with non-OSA control patients. The magnitude of the increase in arterial stiffness appears to be greater in more severely affected OSA patients and in those with other cardiovascular risk factors, such as hypertension. Therefore, arterial stiffness may have a role in the increased risk of cardiovascular complications in OSA. Interestingly, the use of CPAP was found to improve arterial stiffness in patients with OSA. Assessment of arterial stiffness in OSA patients by means of currently available, convenient and noninvasive methods may be an effective method to also monitor disease progression and treatment efficacy.

1 Young T, Peppard PE, Gottlieb DJ. Epidemiology of obstructive sleep apnea: a population health perspective. Am J Respir Crit Care Med 2002; 165: 1217-1239.

2 El Solh AA, Akinnusi ME, Baddoura FH, Mankowski CR. Endothelial cell apoptosis in obstructive sleep apnea: a link to endothelial dysfunction. Am J Respir Crit Care Med 2007; 175: 1186-1191.

3 Levy P, Pepin JL, Arnaud C, Baguet JP, Dematteis M, Mach F. Obstructive sleep apnea and atherosclerosis. Prog Cardiovasc Dis 2009; 51: 400-410.

4 Marshall NS, Wong KK, Liu PY, Cullen SR, Knuiman MW, Grunstein RR. Sleep apnea as an independent risk factor for all-cause mortality: the Busselton Health Study. Sleep 2008; 31: 1079-1085.

5 Young T, Finn L, Peppard PE, Szklo-Coxe M, Austin D, Nieto FJ, Stubbs R, Hla KM. Sleep disordered breathing and mortality: eighteen-year follow-up of the Wisconsin sleep cohort. Sleep 2008; 31: 1071-1078.

6 Marin JM, Carrizo SJ, Vicente E, Agusti AG. Long-term cardiovascular outcomes in men with obstructive sleep apnoea-hypopnoea with or without treatment with continuous positive airway pressure: an observational study. Lancet 2005; 365: 1046-1053.

7 Lavie P, Herer P, Peled R, Berger I, Yoffe N, Zomer J, Rubin AH. Mortality in sleep apnea patients: a multivariate analysis of risk factors. Sleep 1995; 18: 149-157.

8 Dempsey JA, Veasey SC, Morgan BJ, O'Donnell CP. Pathophysiology of sleep apnea. Physiol Rev 2010; 90: 47-112.

9 Pack Al, Gislason T. Obstructive sleep apnea and cardiovascular disease: a perspective and future directions. Prog Cardiovasc Dis 2009; 51: 434-451.

10 McNicholas WT. Obstructive sleep apnea and inflammation. Prog Cardiovasc Dis 2009; 51: 392-399.

11 Punjabi NM, Shahar E, Redline S, Gottlieb DJ, Givelber R, Resnick HE. Sleepdisordered breathing, glucose intolerance, and insulin resistance: the Sleep Heart Health Study. Am J Epidemiol 2004; 160: 521-530. 
12 Punjabi NM, Sorkin JD, Katzel LI, Goldberg AP, Schwartz AR, Smith PL. Sleepdisordered breathing and insulin resistance in middle-aged and overweight men. Am J Respir Crit Care Med 2002; 165: 677-682.

13 Reichmuth KJ, Austin D, Skatrud JB, Young T. Association of sleep apnea and type II diabetes: a population-based study. Am J Respir Crit Care Med 2005; 172 : 1590-1595.

14 Shamsuzzaman AS, Winnicki M, Lanfranchi P, Wolk R, Kara T, Accurso V, Somers VK. Elevated C-reactive protein in patients with obstructive sleep apnea. Circulation 2002; 105: 2462-2464.

15 Yokoe T, Minoguchi K, Matsuo H, Oda N, Minoguchi H, Yoshino G, Hirano T, Adachi M. Elevated levels of C-reactive protein and interleukin- 6 in patients with obstructive sleep apnea syndrome are decreased by nasal continuous positive airway pressure. Circulation 2003; 107: 1129-1134.

16 Punjabi NM, Beamer BA. C-reactive protein is associated with sleep disordered breathing independent of adiposity. Sleep 2007; 30: 29-34.

17 Van Bortel LM, Struijker-Boudier HA, Safar ME. Pulse pressure, arterial stiffness, and drug treatment of hypertension. Hypertension 2001; 38: 914-921.

18 Safar ME, Lacolley P. Disturbance of macro- and microcirculation: relations with pulse pressure and cardiac organ damage. Am J Physiol Heart Circ Physiol 2007; 293: H1-H7.

19 Kroeker EJ, Wood EH. Comparison of simultaneously recorded central and peripheral arterial pressure pulses during rest, exercise and tilted position in man. Circ Res 1955; 3: 623-632.

20 Remington JW, Wood EH. Formation of peripheral pulse contour in man. J App/ Physiol 1956; 9: 433-442.

21 Rowell LB, Brengelmann GL, Blackmon JR, Bruce RA, Murray JA. Disparities between aortic and peripheral pulse pressures induced by upright exercise and vasomotor changes in man. Circulation 1968; 37: 954-964.

22 O'Rourke MF. Arterial pressure waveforms in hypertension. Minerva Med 2003; 94 229-250.

23 Kelly RP, Gibbs HH, O'Rourke MF, Daley JE, Mang K, Morgan JJ, Avolio AP. Nitroglycerin has more favourable effects on left ventricular afterload than apparent from measurement of pressure in a peripheral artery. Eur Heart J 1990; 11: 138-144.

24 Morgan T, Lauri J, Bertram D, Anderson A. Effect of different antihypertensive drug classes on central aortic pressure. Am J Hypertens 2004; 17: 118-123.

25 Laurent S, Cockcroft J, Van BL, Boutouyrie P, Giannattasio C, Hayoz D, Pannier B, Vlachopoulos C, Wilkinson I, Struijker-Boudier H. Expert consensus document on arterial stiffness: methodological issues and clinical applications. Eur Heart J 2006; 27: 2588-2605

26 Mancia G, De BG, Dominiczak A, Cifkova R, Fagard R, Germano G, Grassi G, Heagerty AM, Kjeldsen SE, Laurent S, Narkiewicz K, Ruilope L, Rynkiewicz A, Schmieder RE, Struijker Boudier HA, Zanchetti A, Vahanian A, Camm J, De CR, Dean V, Dickstein K, Filippatos G, Funck-Brentano C, Hellemans I, Kristensen SD, McGregor K, Sechtem U, Silber S, Tendera M, Widimsky P, Zamorano JL, Kjeldsen SE, Erdine S, Narkiewicz K, Kiowski W, gabiti-Rosei E, Ambrosioni E, Cifkova R, Dominiczak A, Fagard R, Heagerty AM, Laurent S, Lindholm LH, Mancia G, Manolis A, Nilsson PM, Redon J, Schmieder RE, Struijker-Boudier HA, Viigimaa M, Filippatos G, Adamopoulos S, gabiti-Rosei E, Ambrosioni E, Bertomeu V, Clement D, Erdine S, Farsang C, Gaita D, Kiowski W, Lip G, Mallion JM, Manolis AJ, Nilsson PM, O'Brien E, Ponikowski P, Redon J, Ruschitzka F, Tamargo J, van ZP, Viigimaa M, Waeber B, Williams B, Zamorano JL. 2007 Guidelines for the management of arterial hypertension: The Task Force for the Management of Arterial Hypertension of the European Society of Hypertension (ESH) and of the European Society of Cardiology (ESC). Eur Heart J 2007; 28: 1462-1536.

27 Lemogoum D, Van BL, Leeman M, Degaute JP, van de BP. Ethnic differences in arterial stiffness and wave reflections after cigarette smoking. J Hypertens 2006; 24 683-689.

28 Laurent S, Boutouyrie P, Asmar R, Gautier I, Laloux B, Guize L, Ducimetiere P, Benetos A. Aortic stiffness is an independent predictor of all-cause and cardiovascular mortality in hypertensive patients. Hypertension 2001; 37: 1236-1241.

29 Boutouyrie P, Tropeano Al, Asmar R, Gautier I, Benetos A, Lacolley P, Laurent S. Aortic stiffness is an independent predictor of primary coronary events in hypertensive patients: a longitudinal study. Hypertension 2002; 39: 10-15.

30 Willum-Hansen T, Staessen JA, Torp-Pedersen C, Rasmussen S, Thijs L, Ibsen H, Jeppesen J. Prognostic value of aortic pulse wave velocity as index of arterial stiffness in the general population. Circulation 2006; 113: 664-670.

31 Mattace-Raso FU, van der Cammen TJ, Hofman A, van Popele NM, Bos ML, Schalekamp MA, Asmar R, Reneman RS, Hoeks AP, Breteler MM, Witteman JC. Arterial stiffness and risk of coronary heart disease and stroke: the Rotterdam Study. Circulation 2006; 113: 657-663.

32 Vlachopoulos C, Aznaouridis K, Stefanadis C. Prediction of cardiovascular events and all-cause mortality with arterial stiffness: a systematic review and meta-analysis. J Am Coll Cardiol 2010; 55: 1318-1327.

33 Hayward CS, Kraidly M, Webb CM, Collins P. Assessment of endothelial function using peripheral waveform analysis: a clinical application. J Am Coll Cardiol 2002; 40: 521-528.

34 Migrino RQ, Aggarwal D, Konorev E, Brahmbhatt T, Bright M, Kalyanaraman B. Early detection of doxorubicin cardiomyopathy using two-dimensional strain echocardiography. Ultrasound Med Biol 2008; 34: 208-214.

35 Maarek B, Simon AC, Levenson J, Pithois-Merli I, Bouthier J. Heterogeneity of the atherosclerotic process in systemic hypertension poorly controlled by drug treatment. Am J Cardiol 1987; 59: 414-417.

36 Wada T, Kodaira K, Fujishiro K, Maie K, Tsukiyama E, Fukumoto T, Uchida T, Yamazaki S. Correlation of ultrasound-measured common carotid artery stiffness with pathological findings. Arterioscler Thromb 1994; 14: 479-482.
37 Claridge MW, Bate GR, Hoskins PR, Adam DJ, Bradbury AW, Wilmink AB. Measurement of arterial stiffness in subjects with vascular disease: are vessel wall changes more sensitive than increase in intima-media thickness? Atherosclerosis 2009; 205 . 477-480.

38 Tzortzis S, Ikonomidis I, Lekakis J, Papadopoulos C, Triantafyllidi H, Parissis J, Trivilou P. Paraskevaidis I, nastasiou-Nana M, Kremastinos DT. Incremental predictive value of carotid intima-media thickness to arterial stiffness for impaired coronary flow reserve in untreated hypertensives. Hypertens Res 2010; 33: 367-373.

39 Vaitkevicius PV, Fleg JL, Engel JH, O'Connor FC, Wright JG, Lakatta LE, Yin FC, Lakatta EG. Effects of age and aerobic capacity on arterial stiffness in healthy adults. Circulation 1993; 88: 1456-1462.

40 Mitchell GF, Parise H, Benjamin EJ, Larson MG, Keyes MJ, Vita JA, Vasan RS, Levy D. Changes in arterial stiffness and wave reflection with advancing age in healthy men and women: the Framingham Heart Study. Hypertension 2004; 43: 1239-1245.

41 Hasegawa M, Nagao K, Kinoshita Y, Rodbard D, Asahina A. Increased pulse wave velocity and shortened pulse wave transmission time in hypertension and aging. Cardiology 1997; 88: 147-151.

42 Tsioufis C, Thomopoulos K, Dimitriadis K, Amfilochiou A, Tousoulis D, Alchanatis M, Stefanadis C, Kallikazaros I. The incremental effect of obstructive sleep apnoea syndrome on arterial stiffness in newly diagnosed essential hypertensive subjects. J Hypertens 2007; 25: 141-146.

43 Drager LF, Bortolotto LA, Figueiredo AC, Silva BC, Krieger EM, Lorenzi-Filho G. Obstructive sleep apnea, hypertension, and their interaction on arterial stiffness and heart remodeling. Chest 2007; 131: 1379-1386.

44 Drager LF, Bortolotto LA, Maki-Nunes C, Trombetta IC, Alves MJ, Fraga RF, Negrao CE, Krieger EM, Lorenzi-Filho $\mathrm{G}$. The incremental role of obstructive sleep apnoea on markers of atherosclerosis in patients with metabolic syndrome. Atherosclerosis 2010; 208: 490-495.

45 Drager LF, Bortolotto LA, Lorenzi MC, Figueiredo AC, Krieger EM, Lorenzi-Filho G. Early signs of atherosclerosis in obstructive sleep apnea. Am J Respir Crit Care Med 2005; 172: 613-618.

46 Drager LF, egues-Silva L, Diniz PM, Bortolotto LA, Pedrosa RP, Couto RB, Marcondes B, Giorgi DM, Lorenzi-Filho G, Krieger EM. Obstructive sleep apnea, masked hypertension, and arterial stiffness in men. Am J Hypertens 2010; 23: 249-254.

47 Chung S, Yoon IY, Lee CH, Kim JW. The association of nocturnal hypoxemia with arterial stiffness and endothelial dysfunction in male patients with obstructive sleep apnea syndrome. Respiration 2010; 79: 363-369.

48 Protogerou AD, Laaban JP, Czernichow S, Kostopoulos C, Lekakis J, Safar ME, Blacher J. Structural and functional arterial properties in patients with obstructive sleep apnoea syndrome and cardiovascular comorbidities. J Hum Hypertens 2008; 22: 415-422.

49 Shiina K, Tomiyama H, Takata Y, Usui Y, Asano K, Hirayama Y, Nakamura T, Yamashina A. Concurrent presence of metabolic syndrome in obstructive sleep apnea syndrome exacerbates the cardiovascular risk: a sleep clinic cohort study. Hypertens Res 2006; 29: 433-441.

50 Nagahama H, Soejima M, Uenomachi H, Higashi Y, Yotsumoto K, Samukawa T, Arima $\mathrm{T}$. Pulse wave velocity as an indicator of atherosclerosis in obstructive sleep apnea syndrome patients. Intern Med 2004; 43: 184-188.

51 Tomiyama H, Takata Y, Shiina K, Matsumoto C, Yamada J, Yoshida M, Yamashina A. Concomitant existence and interaction of cardiovascular abnormalities in obstructive sleep apnea subjects with normal clinic blood pressure. Hypertens Res 2009; 32: 201-206.

52 Kumagai T, Kasai T, Kato M, Naito R, Maeno K, Kasagi S, Kawana F, Ishiwata S, Narui $\mathrm{K}$. Establishment of the cardio-ankle vascular index in patients with obstructive sleep apnea. Chest 2009; 136: 779-786.

53 Kohler M, Craig S, Nicoll D, Leeson P, Davies RJ, Stradling JR. Endothelial function and arterial stiffness in minimally symptomatic obstructive sleep apnea. Am J Respir Crit Care Med 2008; 178: 984-988.

54 Noda A, Nakata S, Fukatsu H, Yasuda Y, Miyao E, Miyata S, Yasuma F, Murohara T, Yokota M, Koike Y. Aortic pressure augmentation as a marker of cardiovascular risk in obstructive sleep apnea syndrome. Hypertens Res 2008; 31: 1109-1114.

55 Tanriverdi H, Evrengul H, Kaftan A, Kara CO, Kuru O, Tanriverdi S, Ozkurt S, Semiz E. Effect of obstructive sleep apnea on aortic elastic parameters: relationship to left ventricular mass and function. Circ J 2006; 70: 737-743.

56 Kasikcioglu HA, Karasulu L, Durgun E, Oflaz H, Kasikcioglu E, Cuhadaroglu C. Aortic elastic properties and left ventricular diastolic dysfunction in patients with obstructive sleep apnea. Heart Vessels 2005; 20: 239-244.

57 Tavil Y, Kanbay A, Sen N, Ulukavak CT, Abaci A, Yalcin MR, Kokturk O, Cengel A. The relationship between aortic stiffness and cardiac function in patients with obstructive sleep apnea, independently from systemic hypertension. J Am Soc Echocardiogr 2007; 20: 366-372.

58 Kohler M, Pepperell JC, Casadei B, Craig S, Crosthwaite N, Stradling JR, Davies RJ. CPAP and measures of cardiovascular risk in males with OSAS. Eur Respir J 2008; 32: 1488-1496.

59 Drager LF, Bortolotto LA, Figueiredo AC, Krieger EM, Lorenzi GF. Effects of continuous positive airway pressure on early signs of atherosclerosis in obstructive sleep apnea. $A m$ J Respir Crit Care Med 2007; 176: 706-712.

60 Keles T, Durmaz T, Bayram NA, Ciftci B, Yeter E, Akcay M, Bozkurt E. Effect of continuous positive airway pressure therapy on aortic stiffness in patients with obstructive sleep apnea syndrome. Echocardiography 2009; 26: 1217-1224.

61 Phillips CL, Yee B, Yang Q, Villaneuva AT, Hedner J, Berend N, Grunstein R. Effects of continuous positive airway pressure treatment and withdrawal in patients with obstructive sleep apnea on arterial stiffness and central BP. Chest 2008; 134: 94-100. 
62 Kitahara Y, Hattori N, Yokoyama A, Nakajima M, Kohno N. Effect of CPAP on brachialankle pulse wave velocity in patients with OSAHS: an open-labelled study. Respir Med 2006; 100: 2160-2169.

63 Shiina K, Tomiyama H, Takata Y, Yoshida M, Kato K, Saruhara H, Hashimura Y, Matsumoto C, Asano K, Usui Y, Yamashina A. Effects of CPAP therapy on the sympathovagal balance and arterial stiffness in obstructive sleep apnea. Respir Med 2010; 104: 911-916.

64 Saito T, Saito T, Sugiyama S, Asai K, Yasutake M, Mizuno K. Effects of long-term treatment for obstructive sleep apnea on pulse wave velocity. Hypertens Res 2010; 33: 844-849.

65 Oflaz H, Cuhadaroglu C, Pamukcu B, Meric M, Ece T, Kasikcioglu E, Koylan N. Endothelial function in patients with obstructive sleep apnea syndrome but without hypertension. Respiration 2006; 73: 751-756.

66 Kato M, Roberts-Thomson P, Phillips BG, Haynes WG, Winnicki M, Accurso V, Somers VK. Impairment of endothelium-dependent vasodilation of resistance vessels in patients with obstructive sleep apnea. Circulation 2000; 102: 2607-2610.

67 Carlson JT, Rangemark C, Hedner JA. Attenuated endothelium-dependent vascular relaxation in patients with sleep apnoea. J Hypertens 1996; 14: 577-584.

68 Kuramoto E, Kinami S, Ishida Y, Shiotani H, Nishimura Y. Continuous positive nasal airway pressure decreases levels of serum amyloid $A$ and improves autonomic function in obstructive sleep apnea syndrome. Int J Cardiol 2009; 135: 338-345.

69 Jelic S, Bartels MN, Mateika JH, Ngai P, DeMeersman RE, Basner RC. Arterial stiffness increases during obstructive sleep apneas. Sleep 2002; 25: 850-855.

70 Lavie L, Lavie P. Molecular mechanisms of cardiovascular disease in OSAHS: the oxidative stress link. Eur Respir J 2009; 33: 1467-1484.

71 Cofta S, Wysocka E, Piorunek T, Rzymkowska M, Batura-Gabryel H, Torlinski L. Oxidative stress markers in the blood of persons with different stages of obstructive sleep apnea syndrome. J Physiol Pharmacol 2008; 59(Suppl 6): 183-190.

72 Lavie L. Oxidative stress - a unifying paradigm in obstructive sleep apnea and comorbidities. Prog Cardiovasc Dis 2009; 51: 303-312.

73 Lui MM, Lam JC, Mak HK, Xu A, Ooi C, Lam DC, Mak JC, Khong PL, Ip MS. C-reactive protein is associated with obstructive sleep apnea independent of visceral obesity. Chest 2009; 135: 950-956.
74 Alzoghaibi MA, Bahammam AS. Lipid peroxides, superoxide dismutase and circulating IL-8 and GCP-2 in patients with severe obstructive sleep apnea: a pilot study. Sleep Breath 2005; 9: 119-126.

75 Blacher J, Asmar R, Djane S, London GM, Safar ME. Aortic pulse wave velocity as a marker of cardiovascular risk in hypertensive patients. Hypertension 1999; 33: 1111-1117.

76 Cruickshank K, Riste L, Anderson SG, Wright JS, Dunn G, Gosling RG. Aortic pulsewave velocity and its relationship to mortality in diabetes and glucose intolerance: an integrated index of vascular function? Circulation 2002; 106: 2085-2090.

77 Waddell TK, Dart AM, Medley TL, Cameron JD, Kingwell BA. Carotid pressure is a better predictor of coronary artery disease severity than brachial pressure. Hypertension 2001; 38: 927-931.

78 Safar ME, Blacher J, Pannier B, Guerin AP, Marchais SJ, Guyonvarc'h PM, London GM. Central pulse pressure and mortality in end-stage renal disease. Hypertension 2002; 39: 735-738.

79 Blacher J, Safar ME, Guerin AP, Pannier B, Marchais SJ, London GM. Aortic pulse wave velocity index and mortality in end-stage renal disease. Kidney Int 2003; 63 : $1852-1860$.

80 Weber T, Auer J, O’Rourke MF, Kvas E, Lassnig E, Lamm G, Stark N, Rammer M, Eber B. Increased arterial wave reflections predict severe cardiovascular events in patients undergoing percutaneous coronary interventions. Eur Heart J 2005; 26: 2657-2663.

81 Phillips C, Hedner J, Berend N, Grunstein R. Diurnal and obstructive sleep apnea influences on arterial stiffness and central blood pressure in men. Sleep 2005; 28 : 604-609.

82 Papaioannou TG, Karatzis EN, Papamichael CM, Karatzi KN, Zakopoulos NA, Lekakis JP, Mavrikakis M, Stefanadis $C$. Circadian variation of arterial pressure wave reflections. Am J Hypertens 2006; 19: 259-263.

83 Muller JE, Stone PH, Turi ZG, Rutherford JD, Czeisler CA, Parker C, Poole WK, Passamani E, Roberts R, Robertson T. Circadian variation in the frequency of onset of acute myocardial infarction. N Engl J Med 1985; 313: 1315-1322.

84 Muller JE, Ludmer PL, Willich SN, Tofler GH, Aylmer G, Klangos I, Stone PH. Circadian variation in the frequency of sudden cardiac death. Circulation 1987; 75: 131-138. 